\title{
Factores determinantes de las conductas de riesgo para ITS - HIV en los estudiantes de las Escuelas de Salud de la Universidad Alas Peruanas, Arequipa
}

\author{
Decisive factors of the behaviors of risk for ITS - HIV \\ in the students of the Schools of Health, \\ of the Universidad Alas Peruanas, Arequipa
}

José Carlos Martínez Montes*

http://dx.doi.org/10.21503/CienciayDesarrollo.2010.v11.05

\section{RESUMEN}

Los estudiantes de las Escuelas de Salud están continuamente expuestos al riesgo de accidentes ocupacionales en los centros asistenciales, donde realizan sus prácticas, así como a una vida sexual activa, en donde el contagio por agentes infecciosos como Hepatitis B, Hepatitis C y HIV, transmisibles por mecanismos relacionados con accidentes de trabajo sanitario y relaciones sexuales entre otros, resultan como consecuencia de las conductas de riesgo, en donde el nivel de conocimientos, las actitudes y el medioambiente social y cultural son factores que las determinan.

El estudio de tipo analítico, prospectivo, transversal, se realizó sobre una muestra de 280 estudiantes de las Escuelas de Tecnología Médica, Enfermería, Odontología y Farmacia de la Universidad Alas Peruanas, Arequipa, que cursaban del cuarto al décimo semestre. A ellos se aplicó el instrumento "Cuestionario de Conductas de Riesgo" por medio de una encuesta anónima.

La investigación demostró que sobre las conductas de riesgo sexual, el $40 \%$ de los estudiantes no conocía las vías de transmisión y las conductas preventivas, colocando a los factores cognitivos como los principales responsables, seguidos de factores socioculturales, como el grupo de amigos que promueven la promiscuidad 10\%; la bisexualidad 8\%; el sexo inseguro 15\%, y los centros de diversión que ofertan licor, drogas y ambientes privados.

Asimismo, las conductas de riesgo ocupacional son principalmente debidas a factores actitudinales, en donde el $60 \%$ de los estudiantes conoce las medidas de protección personal pero desestiman su uso argumentando incomodidad el $40 \%$, seguido de los factores socioculturales que en general se constituye por el personal de salud profesional, técnico y auxiliar que no usa guantes, mandiles, lentes y otros elementos de protección en su práctica asistencial promoviendo esta mala conducta.

La variación de los resultados por escuela profesional no es significativa, siendo la Escuela de Enfermería la de menor riesgo ocupacional, y la Escuela de Tecnología Médica la de menor riesgo sexual en sus estudiantes.

Palabras clave: riesgo ocupacional, riesgo sexual, conducta de riesgo, factores determinantes.

* Docente de la Escuela de Tecnología Médica de la Universidad Alas Peruanas, Filial Arequipa. 


\section{ABSTRACT}

The students of the Schools of Health are continually exposed to the risk of occupational accidents in the assistance centers, where they carry out their practices, as well as to a sexual active life where the infection for infectious agents as Hepatitis B, Hepatitis C and HIV, transferable for mechanisms related with industrial accidents sanitarium and sexual relationships among other, they are as consequence of the behaviors of risk where the level of knowledge, the attitudes and the social and cultural medioambiente are factors that determine them.

The study of analytic, prospective, traverse type, was carried out on a sample of 280 students of the Schools of Medical Technology, Infirmary, Dentistry and Pharmacy of the University Peruvian Wings, Arequipa that you/they studied from the room to the tenth semester. To them the instrument "Questionnaire of Behaviors of Risk" was applied by means of an anonymous survey.

The investigation demonstrated that it has more than enough the behaviors of sexual risk, $40 \%$ of the students didn't know the transmission roads and the preventive behaviors, placing to the factors cognitivos like the main ones responsible, followed by sociocultural factors, as the group of friends that promote the promiscuity $10 \%$; the bisexuality $8 \%$; the sex insecure $15 \%$, and the centers of amusement that offer liquor, drugs and private atmospheres.

Also, the behaviors of occupational risk are mainly due to factors actitudinales where $60 \%$ of the students knows the measures of personal protection but they underrate its use arguing annoyance $40 \%$, followed by the sociocultural factors that it is constituted by the personnel of professional health in general, technician and auxiliary that doesn't use gloves, aprons, eyeglasses and other protection elements in its assistance practice promoting this bad behavior.

The variation of the results for professional school is not significant, being the School of Infirmary that of occupational smaller risk, and the School of Medical Technology that of sexual smaller risk in its students.

Words key: occupational risk, sexual risk, behavior of risk, decisive factors.

\section{INTRODUCCIÓN}

La universidad es un medio socializador complejo que impacta profundamente en los estudiantes que interactúan con los docentes, la comunidad estudiantil, el medio social y físico que los rodea, instalando conductas adaptativas para vivir en equilibrio en un medio que generalmente es muy exigente y de continuos riesgos, especialmente para los adolescentes, que tienen que aprender a decidir por conductas saludables alejándose de las drogas, el alcohol, el sexo irresponsable, entre otras decisiones que lo llevarán a ser una persona y profesional exitoso.

En este contexto, los estudiantes de las escuelas de salud con una vida sexual activa se exponen, entre otros riesgos, al contagio por ITS-
HIV; así como también están continuamente expuestos al riesgo de accidentes ocupacionales en los centros asistenciales, donde realizan sus prácticas, y donde el contagio por estos agentes infecciosos es de alto riesgo, estando relacionado con actitudes y el nivel de conocimientos de los estudiantes, así como de las conductas de riesgo que adopta el personal de salud del servicio en que se forman.

\section{MATERIAL Y MÉTODO}

\section{Muestra:}

280 estudiantes estratificados por escuelas profesionales de salud (70 estudiantes de Tecnología Médica, 70 estudiantes de 
Enfermería, 70 estudiantes de Odontología y 70 estudiantes de Farmacia) de la Universidad Alas Peruanas, Filial Arequipa, que cursan del cuarto al décimo semestre.

\section{Procedimiento}

El instrumento "Cuestionario de Conductas de Riesgo” se aplicó a 70 alumnos de cada una de las escuelas profesionales de salud (Tecnología Médica, Enfermería, Odontología y Farmacia), por medio de una encuesta anónima, para medir cómo afecta la variable independiente Factores Determinantes a la variable dependiente Conductade riesgo a ITS-HIV, en los estudiantes de las escuelas de salud de la Universidad Alas Peruanas, filial Arequipa.

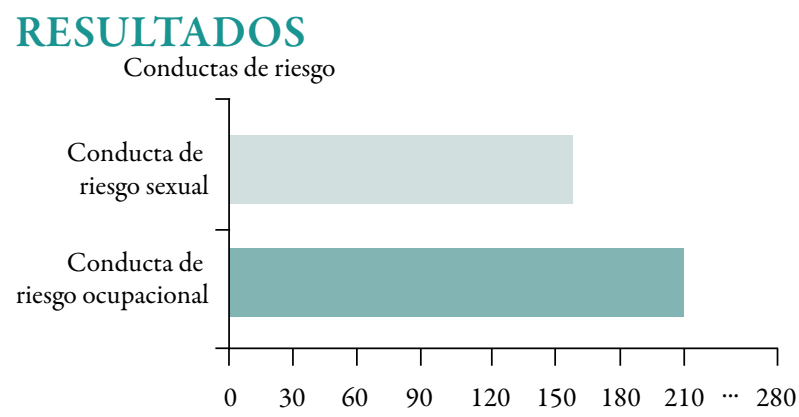

Figura 1. Distribución de conductas de riesgo en los estudiantes de las escuelas de salud.

La Figura 1 muestra que las conductas de riesgo ocupacional con 210 estudiantes (75\%), son más frecuentes que las de riesgo sexual con 160 estudiantes (57\%) para infecciones de transmisión sexual y HIV, en las escuelas profesionales de salud de la UAP, Filial Arequipa.

En la Figura 2 se observa que la distribución de las conductas de riesgo a ITS-HIV en las escuelas profesionales de salud no tienen una variación significativa, siendo los estudiantes de Odontología los de mayor conducta de riesgo ocupacional con 58 estudiantes (82.8\%) y sexual con 48 estudiantes (68.5\%). Asimismo,

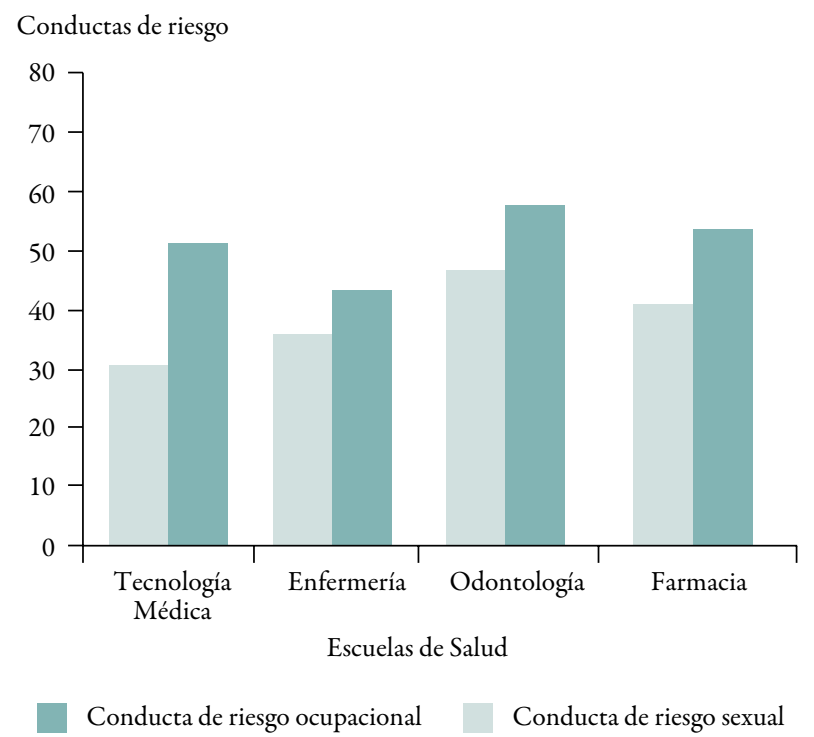

Figura 2. Distribución de conductas de riesgo a ITSHIV por escuelas profesionales de salud.

la Escuela de Tecnología Médica, con 32 estudiantes (45,7\%), es la de menor conducta de riesgo sexual, y la escuela de Enfermería, con 46 estudiantes (65,7\%), es la de menor conducta de riesgo ocupacional.

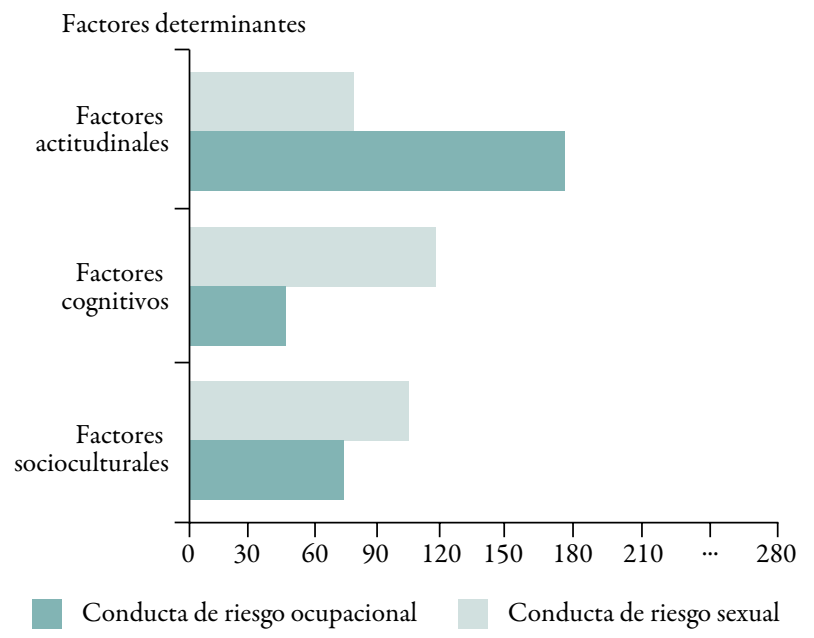

Figura 3. Distribución de factores determinantes por riesgo ocupacional y sexual.

La Figura 3 muestra la distribución de los factores determinantes a ITS-HIV por riesgo ocupacional y sexual, donde los factores actitudinales con 168 estudiantes de las escuelas profesionales de salud $(60 \%$ de los entrevistados) son los principales determinantes de las conductas riesgo ocupacional, y los 
factores cognitivos con 112 estudiantes de las escuelas de salud ( $40 \%$ de los entrevistados) son responsables de las conductas de riesgo sexual. Los factores socioculturales son significativos en las conductas de riesgo sexual con el $32.8 \%$ de los entrevistados ( 92 estudiantes) y ocupacional con el 25\% de los entrevistados (70 estudiantes).

\section{CONCLUSIONES}

1. Las conductas de riesgo ocupacional son más frecuentes que las conductas de riesgo sexual para ITS-HIV, en los estudiantes de las escuelas de salud de la UAP-Arequipa.

2. No existe variación significativa entre las conductas de riesgo a ITS-HIV, por escuelas profesionales de salud en la UAP-Arequipa.

3. Los factores cognitivos son los principales determinantes de las conductas de riesgo sexual para ITS-HIV, en los estudiantes de las escuelas de salud de la UAP-Arequipa.

4. Los factores actitudinales son los principales determinantes de las conductas de riesgo ocupacional para ITS-HIV, en los estudiantes de las escuelas de salud de la UAP-Arequipa.

5. Los factores socioculturales están relacionados con las conductas de riesgo sexual y ocupacional en los estudiantes de las escuelas profesionales de salud, en la UAP-Arequipa.

\section{DISCUSIÓN}

El instrumento elaborado para medir el impacto de los factores cognitivos, actitudinales y socioculturales en las conductas de riesgo sexual y ocupacional a ITS-HIV, permite entender que el nivel de conocimiento de los estudiantes sobre sexualidad es preocupante, pues no conocían las vías de transmisión, las conductas preventivas de enfermedades, las conductas sexuales saludables entre otros aspectos de la sexualidad humana, colocando a los factores cognitivos como los principales responsables, seguidos de factores socioculturales como el grupo de amigos que promueven la promiscuidad $10 \%$, la bisexualidad $8 \%$, el sexo inseguro $15 \%$, y los centros de diversión que ofertan licor, drogas y ambientes privados, con acceso libre, incluso a menores de edad.

Asimismo, las conductas de riesgo ocupacional son principalmente debidas a factores actitudinales, pues los estudiantes conocen las medidas de protección personal, pero desestiman su uso, argumentando incomodidad. Esto, sumado a los factores socioculturales, donde el personal de salud profesional, técnico y auxiliar que no usa guantes, mandiles, lentes y otros elementos de protección en su práctica asistencial promueve esta mala conducta, infundiéndola en los estudiantes. 